\title{
Microbial modulating effect of xylanase enzyme supplemented rice husk on the
} gastrointestinal tract of broiler chickens

Aderibigbe, T. A., Atteh, J. O. and Okukpe, K. M.*

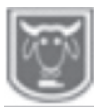

Abstract
Department of Animal Production, Faculty of Agriculture,

University of Ilorin, PMB 1515, Ilorin, Kwara State, Nigeria.*

okukpekehinde@yahoo.com or tabithanov23@yahoo.com;

The development of antibiotics-resistance pathogens in poultry which poses threat to human health has necessitated the search for alternative to antibiotic growth promoters (AGPS) to improve gut microflora in poultry diets. One of the alternatives to AGPs is probiotics which are beneficial organisms. The prebiotic potentials of enzyme supplemented high fibre feedstuffs (HFFs) are not known. This study was conducted to assess the prebiotics potential of xylanase enzyme supplemented rice husk (RH) on broiler chickens (in-vivo). The study showed that replacement of maize with RH irrespective of levels supplemented with 100ppm xylanase enzyme caused a reduction in feed intake and an increase in weight gain and better FCR. It was observed that birds fed diet with $10 \%$ RH supplemented with xylanase enzyme out-performed birds fed diets with 20 or 30\% RH supplemented with xylanase enzyme and closer to the birds fed the control diet which was with better FCR. Enzyme supplementation of $R H$ helped in increasing and improving protein, ether extract and fibre digestibilities. The identification of microbes (Fungi and Bacteria) showed that dietary levels of RH (10, 20 or $30 \%$ inclusion) with supplementation of enzyme xylanase enhanced the growth of beneficial microbes which resulted in inhibition or elimination of the opportunistic/pathogenic microbes. The result of the cost benefit analysis also showed that $10 \%$ inclusion level of RH supplemented with xylanase enzyme gave the best result of a beneficiary reduction in the cost of production with the best improved broiler performance. The use of enzymes is therefore recommended when $R H$ are required as prebiotic source in the gut of broilers.

Keywords: prebiotics, enzymes, intestinal microflora, digestibility, broiler nutrition

\section{Introduction}

Feed ingredients that are non-digestible or of low digestibility and selectively stimulate the growth of limited number of gut microbiota species are referred to as prebiotics, it confers health benefits to its host (Roberfroid 2007; Binns 2013). They are oligosaccharides and polysaccharides and function as a result of being resistant to gastric acidity and hydrolysis by mammalian enzyme, ease of fermentation by intestinal microflora, and its ability to selectively stimulate growth of intestinal bacteria (Roberfroid, 2007; Bruggencate et al., 2008). Reported examples of prebiotics include galactooligosaccharides (GOS), fructo-oligoaccharides (FOS), soybean oligos a c charides, is o maltooligosaccharides, inulin and lactulose (Baurhoo et al., 2007). Others include Xylo-oligosaccharides (XOS) which consists of xylobiose and xylotriose (Li et al., 2008; Binns, 2013). Prebiotics are naturally found in fruits, vegetables, bamboo, honey and milk. It can be produced from xylan rich lignocellulosic wastes.

Rice husk is a by-product in the rice-milling industry with a lignocellulosic biomass and accounts for about 40 million metric tonnes of wastes from more than 500 million metric tonnes of the world's annual paddy rice production. Its composition is made up of $15-20 \%$ oil, $12-16 \%$ protein, $6.5 \%$ 


\section{Microbial modulating effect of xylanase enzyme}

oligosaccharides, 35-55\% other carbohydrates and $7-10 \%$ silica and other micro elements (Wang et al., 2005). It has a high phytate content which makes it prone to rancidity, high in fibre and contains a trypsin inhibitor (Gallinger et al., 2004). Some of these characteristics are responsible for its limited use in poultry diets but this limitation could be reduced with enzyme supplementation. Exogenous microbial enzymes have long been used to improve the nutritional value of high fiber diets (Angelovicova et al., 2005; Selle and Ravindran, 2007). However, there is little or no information on the prebiotics potentials of enzyme supplemented rice bran in Chickens. Thus, this study is designed to assess the effect of prebiotics from rice bran on broiler chickens (invivo).

\section{Materials and methods \\ Sourcing and management of birds}

A total of one thousand, nine hundred and twenty $(1,920)$ day old broiler chicks of Arbor Acre strain purchased from Yammfy Farm hatchery at Ilemona, Kwara State were used for this experiment. The birds were housed in an electrically heated battery cage and fed the experimental diet shown in Table 1. Xylanase enzyme used is a bacteria xylanase feed enzyme (Nutrase, a pure endo-1, 4-beta-xylanase) produced by Bacillus subtilis to break down the arabinoxylan fraction into shorter polysaccharide (xylose monomers) with a decrease of viscosity, liberation of nutrients and improved zoo-technical performances. It was supplied by Nutrex, Belgium. The study was conducted following the guidelines of the Research Policy of the University of Ilorin on Animal Welfare and Ethics which adheres to the "Guide to the Care and Use of Experimental Animal Care" (Canadian Council on Animal Care guidelines, 1984).

\section{Experimental design}

Birds were fed a control diet ( $50 \%$ maize) or diets in which rice husk was added at 10,20, or $30 \%$ replacing maize in the control diet. Each of these diets was given with or without 100 PPM xylanase enzyme in a $4 \mathrm{x}$ 2 factorial combination. Thus, there were 8 treatments each with 8 replicate cages of 30 birds. The experimental diets were formulated to meet NRC (1994) nutrient requirements for broiler, in particular the recommendations for Arbor Acre strain. Each experimental treatment was fed $a d$ libitum with its own diet for a period of five weeks. Live weight was recorded weekly while feed intake was recorded daily in grams and excreta samples collected over a 72 hour period. Nutrient retention trial was done at the third week of the feeding trial using a total collection method. Excreta samples were oven dried at $70^{\circ} \mathrm{C}$, weighed and ground prior to chemical analysis. The experimental diets and excreta samples were analyzed for their chemical constituents using the procedures outlined by AOAC (2008).

Table 1: Composition of experimental diet (\%)

\begin{tabular}{|c|c|c|c|c|c|c|c|c|}
\hline \multirow[b]{2}{*}{ Ingredients } & \multicolumn{8}{|c|}{ Treatments } \\
\hline & 1 & 2 & 3 & 4 & 5 & 6 & 7 & 8 \\
\hline Maize & 50 & 50 & 40 & 40 & 30 & 30 & 20 & 20 \\
\hline Rice Husk & 0 & 0 & 10 & 10 & 20 & 20 & 30 & 30 \\
\hline Xylanase (ppm) & 0 & 100 & 0 & 100 & 0 & 100 & 0 & 100 \\
\hline Basal ingredients & 50 & 50 & 50 & 50 & 50 & 50 & 50 & 50 \\
\hline Total & 100 & 100 & 100 & 100 & 100 & 100 & 100 & 100 \\
\hline
\end{tabular}




\section{Aderibigbe, Atteh and Okukpe}

At the end of the experiment, 10 birds per replicate from each treatment were randomly selected and euthanized by bleeding through the carotid artery for collection of digesta from the gastrointestinal tract (GIT) to determine the microbial profile. The carcasses were subsequently opened and the entire GIT removed using aseptic techniques. It was excised and the luminal contents of the crop, jejunum, duodenum, ileum and caecum were collected and pooled together according to the procedure described by Kalantar et al. (2014). This was done to determine population and profile of microorganisms present in the broiler gut. Five grams of each sample was put into sterile universal bottle containing $100 \mathrm{ml}$ of sterile water and shaken thoroughly. The mixture was allowed to settle and the supernatant decanted into separate test tubes; this serves as stock solution. Serial dilutions of the stock were made and $0.1 \mathrm{ml}$ aliquot was spread on Potato Dextrose Agar (PDA) plate containing 1\% streptomycin (to inhibit bacterial growth). The plates were incubated at room temperature (27 $31^{\circ} \mathrm{C}$ ) for 48 hours (Bengmark, 2001). After incubation, representative fungal colonies were picked from each plate and purified on fresh PDA (for other fungi) and YPDA (Yeast Peptone Dextrose Agar) plates for yeast. The purified isolates were transferred to PDA and YPDA slants incubated at room temperature for 48 hours and stored at $4^{\circ} \mathrm{C}$. The isolates were identified according to the scheme of Chio et al. (1994). In isolation of bacteria, identification was based on the basis of their Gram's reaction and biochemical tests with reference to Bergey's manual of determinative bacteriology.

The direct culturing of the samples was carried out by pipetting $1 \mathrm{ml}$ of the dissolved sample in sterile distilled water asceptically on sterile Petri-dishes. Pour plate technique was used with the NA(Nutrient Agar) plates incubated at $35^{\circ} \mathrm{C}$ for 2-3 days. Bacteria were identified in their unique colonies. They were subcultured by streaking out on Nutrient Agar. Bacterial cells on NA took 23 days at $35^{\circ} \mathrm{C}$ before their pure cultures were stored on slants containing Nutrient agar for bacteria and later stored at $4^{\circ} \mathrm{C}$. These slants served as stock culture for bacteria. Other tests were carried out to identify the morphological and biochemical characteristics of the microbes such as Gram's staining reaction, spore staining, motility test, catalase test, Voges-Proskauer test, methyl-red test, starch hydrolysis, casein hydrolysis, gelatin hydrolysis, oxidase test, indole test, nitrate reduction, sugar fermentation test, growth at different temperature, $\mathrm{NaCl}$ concentration, anaerobic growth, citrate utilization test, hydrogen sulphide production, urease test, acid production, sporulation test, growth in liquid medium at varying temperature, $\mathrm{NaCl}$ solution, and deamination of amino acid test.

\section{Cost-benefit analysis}

Cost-benefit analysis was carried out, taking into consideration the cost of maize, rice husk and the enzyme (xylanase) as they related to the performance of birds.

\section{Statistical analysis}

All Data collected were subjected to twoway analysis of variance (ANOVA) using the PRO GLM (General Linear Model) of SAS (2008) at 5\% level of significance. All significantly different means were separated using the Duncan's Multiple Range Test of the same software package.

\section{Results}

Table 2 shows the effects of dietary levels of rice husk (RH) with or without enzyme supplementation on the performance of broilers. Increase in dietary levels of $\mathrm{RH}$ from $0 \%$ to $30 \%$ had a significant effects on the feed intake, Weight gain and feed 


\section{Microbial modulating effect of xylanase enzyme}

conversion ratio $(\mathrm{p}<0.05)$. Feed intake by birds fed the control diets was significantly lower than those of birds fed diets with dietary levels of RH $(\mathrm{p}<0.05)$. Feed intake by birds fed diet with $30 \% \mathrm{RH}$ was significantly higher than those of birds fed diets with $10 \%$ or $20 \% \mathrm{RH} \quad(\mathrm{p}<0.05)$. Weight gain by birds fed the control diet was significantly higher than those of birds fed with dietary levels of $\mathrm{RH}(\mathrm{p}<0.05)$. Birds fed diet with $10 \%$ RH gained more weight than those of birds fed diets with
$20 \%$ or $30 \% \mathrm{RH}(\mathrm{p}<0.05)$. Feed gain ratio of birds fed the control was significantly lower than those of birds fed with dietary levels of RH $(p<0.05)$. Feed gain ratio by birds fed diet with $30 \%$ rice husk was significantly higher than those of birds fed diets with $10 \%$ or $20 \% \mathrm{RH}(\mathrm{p}<0.05)$. Thus, birds fed the control diet had better feed conversion ratio. Enzyme supplementation had significant decreased effects on Feed intake and Feed/gain ration but significant increased effect on the weight gain $(\mathrm{p}<0.05)$.

Table 2: Effects of dietary levels of rice husk (RH) with or without xylanase supplementation on performance and nutrient retention of broilers $(0-5 \mathrm{wks})$

\begin{tabular}{cllllll}
\hline RH (\%) & $\begin{array}{l}\text { Feed } \\
\text { consumed } \\
\text { (g/bird/day) }\end{array}$ & $\begin{array}{l}\text { Weight gain } \\
\text { (g/bird/day) }\end{array}$ & FCR & $\begin{array}{l}\text { Crude } \\
\text { protein } \\
(\%)\end{array}$ & $\begin{array}{l}\text { Crude } \\
\text { fibre } \\
(\%)\end{array}$ & $\begin{array}{l}\text { Ether } \\
\text { extract } \\
(\%)\end{array}$ \\
\hline 0 & $55.10^{\mathrm{c}}$ & $32.60^{\mathrm{a}}$ & $1.70^{\mathrm{d}}$ & $83.10^{\mathrm{a}}$ & $73.80^{\mathrm{a}}$ & $74.30^{\mathrm{a}}$ \\
10 & $57.20^{\mathrm{b}}$ & $27.60^{\mathrm{b}}$ & $2.10^{\mathrm{c}}$ & $69.20^{\mathrm{b}}$ & $63.60^{\mathrm{b}}$ & $57.40^{\mathrm{b}}$ \\
20 & $56.90^{\mathrm{b}}$ & $25.30^{\mathrm{c}}$ & $2.30^{\mathrm{b}}$ & $59.00^{\mathrm{c}}$ & $61.60^{\mathrm{bc}}$ & $56.90^{\mathrm{b}}$ \\
30 & $58.90^{\mathrm{a}}$ & $23.80^{\mathrm{d}}$ & $2.50^{\mathrm{a}}$ & $55.60^{\mathrm{d}}$ & $59.20^{\mathrm{c}}$ & $54.70^{\mathrm{b}}$ \\
$\mathrm{SE}$ & 0.21 & 0.32 & 0.03 & 0.89 & 0.95 & 1.52 \\
\hline
\end{tabular}

Enzyme supplementation

(ES)(ppm)

\begin{tabular}{|c|c|c|c|c|c|c|}
\hline $\begin{array}{l}0 \\
0\end{array}$ & $57.40^{\mathrm{a}}$ & $26.20^{\mathrm{b}}$ & $2.20^{\mathrm{a}}$ & $62.70^{\mathrm{b}}$ & $60.70^{\mathrm{b}}$ & $58.10^{\mathrm{b}}$ \\
\hline 100 & $56.70^{\mathrm{b}}$ & $28.50^{\mathrm{a}}$ & $2.00^{\mathrm{b}}$ & $70.80^{\mathrm{a}}$ & $68.50^{\mathrm{a}}$ & $63.50^{\mathrm{a}}$ \\
\hline SEM \pm & 0.15 & 0.22 & 0.02 & 0.63 & 0.67 & 1.07 \\
\hline RH $\times$ ES & 0.1399 & 0.0015 & 0.0204 & $\mathrm{~S}$ & NS & NS \\
\hline
\end{tabular}

Table 3: The detail of Interaction on Crude Protein

\begin{tabular}{lllll}
\hline \multicolumn{5}{c}{ Dietary rice husk supplementation (\%) } \\
\hline ES (100ppm) & 0 & 10 & 20 & 30 \\
$\mathbf{0}$ & $80.1^{\mathrm{b}}$ & $60.2^{\mathrm{c}}$ & $55.2^{\mathrm{d}}$ & $55.2^{\mathrm{d}}$ \\
$\mathbf{1 0 0}$ & $86.0^{\mathrm{a}}$ & $78.1^{\mathrm{b}}$ & $62.8^{\mathrm{c}}$ & $56.1^{\mathrm{d}}$ \\
\hline
\end{tabular}

Table 4 shows cost benefit analysis for replacing Maize with $\mathrm{RH}$ with or without enzyme supplementation. The percentage reduction to raise $1 \mathrm{~kg}$ of broiler occurred at $0 \% \mathrm{RH}$ inclusion level with enzyme supplementation. The percentage reduction was $4.35 \%$ as compared to the control diet. The other treatments with or without enzyme supplementation lead to a percentage increase in the cost of raising $1 \mathrm{Kg}$ broiler with $10 \% \mathrm{RH}$ inclusion without enzyme supplementation recording the highest cost of raising $1 \mathrm{Kg}$ broiler as compared to the control diet. This shows that birds on enzyme supplemented $10 \%$ $\mathrm{RH}$ diet were able to produce $1 \mathrm{~kg}$ of meat at a reduced cost when compared to the control. 


\section{Aderibigbe, Atteh and Okukpe}

Table 4 : Cost benefit analysis for replacing maize with rice husk $(\mathrm{RH})$ with or without enzyme supplementation

\begin{tabular}{|c|c|c|c|}
\hline $\begin{array}{l}\text { Cost of } \\
\text { producing/kg } \\
\text { (N) }\end{array}$ & $\begin{array}{l}\text { Percentage } \\
\text { reduction to } \\
\text { raise } 1 \mathrm{Kg} \text { of } \\
\text { Broilers }(\%)\end{array}$ & $\begin{array}{l}\text { Cost of raising } \\
1 \mathrm{~kg} \text { of Broilers } \\
\text { (N) }\end{array}$ & $\begin{array}{l}\text { Percentage } \\
\text { reduction to } \\
\text { raise } 1 \mathrm{~kg} \text { of } \\
\text { Broilers }(\%)\end{array}$ \\
\hline
\end{tabular}

Source of variation

\begin{tabular}{|c|c|c|c|c|c|}
\hline \multicolumn{6}{|c|}{ Enzyme*Treatment } \\
\hline \multicolumn{2}{|c|}{ Non- Inclusion 0} & 111.49 & 0.00 & 195.11 & 0.00 \\
\hline \multicolumn{2}{|c|}{ Non- Inclusion 10} & 105.49 & 5.69 & 241.83 & -23.81 \\
\hline \multicolumn{2}{|c|}{ Non- Inclusion 20} & 99.5 & 12.05 & 232.83 & -19.33 \\
\hline \multicolumn{2}{|c|}{ Non- Inclusion 30} & 93.49 & 16.14 & 239.33 & -22.67 \\
\hline Inclusion & 0 & 114.49 & -2.62 & 186.62 & 4.35 \\
\hline Inclusion & 10 & 108.49 & 2.69 & 205.05 & -5.09 \\
\hline Inclusion & 20 & 102.5 & 8.77 & 221.05 & -13.48 \\
\hline Inclusion & 30 & 98.49 & 13.20 & 236.38 & -21.15 \\
\hline
\end{tabular}

Table 5 shows the effects of dietary levels of RH with or without enzyme supplementation on organs and body parts expressed in percentage live body weight of broilers. Increase in dietary levels of $\mathrm{RH}$ from 0 to $30 \%$ had no significant effect on the heart, proventriculus, bursa of fabricius, neck, wings, crop, full and empty gizzard, and breast weights, liver, head, drumstick, shanks and thighs weights $(\mathrm{p}>0.05)$. However, there were significant effects on the weights of Back, Abdominal fat and Spleen $(p<0.05)$. Back weight of birds fed the control diet was significantly higher than birds fed diet with $30 \% \mathrm{RH}(\mathrm{p}<0.05)$, and comparable with those of birds fed diets with $10 \%$ or $20 \% \mathrm{RH}(\mathrm{p}>0.05)$. Back weight of birds fed diets with $\mathrm{RH}$ irrespective of levels were comparable ( $>0.05$ ). The abdominal fat weight of birds fed the control diet was significantly higher than those of birds fed diets with $\mathrm{RH}$ $(p<0.05)$. Abdominal fat weight of birds fed diets with RH irrespective of levels were comparable $(\mathrm{p}>0.05)$. Weight of spleen for birds fed the control diet was significantly higher than those of birds fed diets with RH $(p<0.05)$. Spleen weight for birds fed diet with $20 \%$ RH was comparable with those fed diets with $10 \%$ and $30 \% \mathrm{RH}(\mathrm{p}>0.05)$. There were no significant effects of enzyme supplementation on all the parameters except for spleen. There was decreased significant effect by enzyme supplementation on the weight of spleen $(p<0.05)$. There was no significant interaction between inclusion of enzymes and dietary levels of $\mathrm{RH}$ on all the parameters $(\mathrm{p}>0.05)$.

Table 6 shows the effects of dietary levels of RH with or without enzyme supplementation on the microbial gut profile of broilers. Increase in dietary levels of $\mathrm{RH}$ from $0 \%$ to $30 \%$ had significant effects on the TVC, TCC, LBC, FC, and pH $(\mathrm{p}<0.05)$, but no significant effect for FCC $(\mathrm{p}>0.05)$. TVC for birds the control diets was significantly lower than birds fed diet with $20 \%$ RH $(p<0.05)$, and comparable with those of birds fed diets with $10 \%$ or $30 \% \mathrm{RH}(\mathrm{p}>0.05)$. TVC for birds fed diets with rice husk irrespective of levels were comparable $(\mathrm{p}>0.05)$. TCC for birds fed control diet and birds fed diet with $10 \% \mathrm{RH}$ were comparable $(p>0.05)$, but significantly lower than those fed diets with $20 \%$ or $30 \%$ RH $(p<0.05)$. TCC for birds fed diets with $\mathrm{RH}$ irrespective of levels were comparable ( $p>0.05)$. LBC for birds fed control diet was significantly lower than those of birds fed diets with $10 \%$ or $20 \%$ $\mathrm{RH}(\mathrm{p}<0.05)$, but comparable with birds fed diet with $30 \% \mathrm{RH}(\mathrm{p}<0.05)$. LBC for birds fed diets with rice husk irrespective of 
Microbial modulating effect of xylanase enzyme

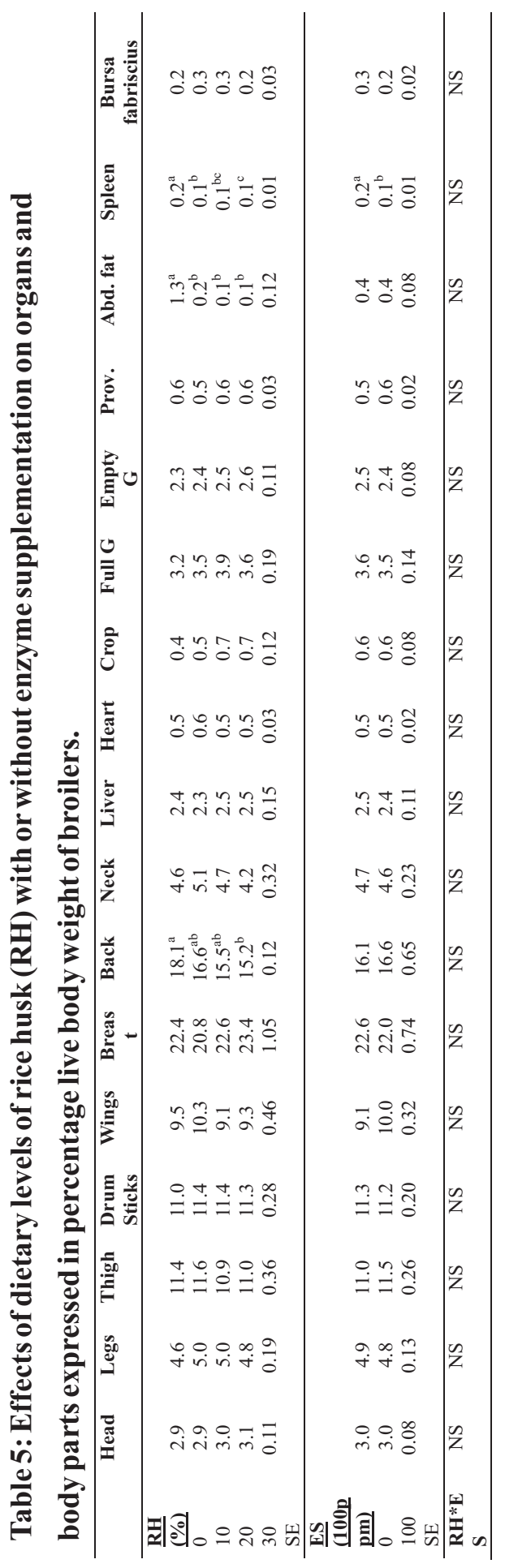




\section{Aderibigbe, Atteh and Okukpe}

levels were comparable ( $p>0.05)$. FC for birds the control diets was significantly lower than birds fed diet with $20 \% \mathrm{RH}$ $(p<0.05)$, and comparable with those of birds fed diets with $10 \%$ or $30 \% \mathrm{RH}$ ( $p>0.05$ ). FC for birds fed diet with $20 \%$ RH was significantly higher than those of birds fed diets with $10 \%$ or $30 \%$ $\mathrm{RH}(\mathrm{p}<0.05) . \mathrm{pH}$ for birds fed the control diet and birds fed diet with $20 \% \mathrm{RH}$ was comparable $(p>0.05)$, but significantly lower than those birds fed diets with $10 \%$ or $30 \% \mathrm{RH}(\mathrm{p}<0.05) . \mathrm{pH}$ for birds fed diets with RH irrespective of levels were comparable $(p>0.05)$. Enzyme supplementation had no significant effects on all the parameters $(p>0.05)$, except significant decreased effect on the FCC $(p<0.05)$. There was no significant interaction between enzyme supplementation and dietary levels of rice husk on the TVC, TCC, FCC, LBC, FC and $\mathrm{pH}(\mathrm{p}>0.05)$.

Table 6: Effects of dietary levels of rice husk $(\mathrm{RH})$ with or without enzyme supplementation on the microbial gut profile of broilers.

\begin{tabular}{|c|c|c|c|c|c|c|}
\hline & $\begin{array}{l}\text { TVC } \\
\left(10^{7} \mathrm{cfu} / \mathrm{ml}\right)\end{array}$ & $\begin{array}{l}\text { TCC } \\
\left(10^{7} \mathrm{cfu} / \mathrm{ml}\right)\end{array}$ & $\begin{array}{l}\text { FCC } \\
\left(10^{7} \mathrm{cfu} / \mathrm{ml}\right)\end{array}$ & $\begin{array}{l}\text { LBC } \\
\left(10^{7} \mathrm{cfu} / \mathrm{ml}\right)\end{array}$ & $\begin{array}{l}\text { FC } \\
\left(10^{5} \mathrm{cfu} / \mathrm{ml}\right)\end{array}$ & pH \\
\hline \multicolumn{7}{|l|}{ RH (\%) } \\
\hline 0 & $5.8^{\mathrm{b}}$ & $4.7^{\mathrm{b}}$ & 2.4 & $1.3^{\mathrm{b}}$ & $1.5^{\mathrm{b}}$ & $5.5^{\mathrm{b}}$ \\
\hline 10 & $6.5^{\mathrm{ab}}$ & $5.3^{\mathrm{ab}}$ & 1.7 & $1.8^{\mathrm{a}}$ & $1.8^{\mathrm{b}}$ & $5.8^{\mathrm{a}}$ \\
\hline 20 & $7.0^{\mathrm{a}}$ & $5.9^{\mathrm{a}}$ & 1.7 & $2.1^{\mathrm{a}}$ & $2.4^{\mathrm{a}}$ & $5.7^{\mathrm{ab}}$ \\
\hline 30 & $6.5^{\mathrm{ab}}$ & $5.8^{\mathrm{a}}$ & 1.7 & $1.8^{\mathrm{ab}}$ & $1.5^{\mathrm{b}}$ & $5.7^{\mathrm{a}}$ \\
\hline SE & 0.33 & 0.26 & 0.37 & 0.18 & 0.17 & 0.04 \\
\hline \multicolumn{7}{|l|}{ Enzyme (100ppm) } \\
\hline$\overline{0}$ & 6.2 & 5.6 & $2.6^{\mathrm{a}}$ & 1.0 & 1.0 & 5.7 \\
\hline 100 & 6.6 & 5.3 & $1.2^{\mathrm{b}}$ & 2.9 & 1.9 & 5.7 \\
\hline SE & 0.24 & 0.18 & 0.26 & 0.13 & 0.12 & 0.03 \\
\hline RH*ES & NS & NS & NS & NS & NS & NS \\
\hline
\end{tabular}

Table 7 shows the effects of dietary levels of RH with or without enzyme supplementation on the summary of the identified fungi in the crop, ileum and caecum pooled together. Increase in dietary levels of rice husk from 0 to $30 \%$ had no effect on both the number of beneficial fungi and the pathogenic/opportunistic fungi identified in the gut of the birds. Saccharomyces cerevisiae was the only beneficial fungus identified in the gut of bird fed the control diet and those birds fed diets with dietary levels of RH. Four species of opportunistic/pathogenic fungi namely; Fusarium solani, Rhizopus stolonifer, Aspergillus niger and Aspergillus flavus were identified in the gut of birds fed the control diet and those birds fed diets with dietary levels of RH. Enzyme supplementation of the dietary levels of RH had increase effect on the number of beneficial fungi identified and a decrease effect on the number of the opportunistic/pathogenic fungi identified in the gut of the birds. Two beneficial fungi species were identified in the gut of those birds fed diets with enzyme supplemented dietary levels of RH namely; Penicilium chrysogenum and Saccharomyces cerevisiae while birds fed the control diet with enzyme supplementation had only Saccharomyces cerevisiae identified in their gut. In the gut of birds fed the control diet with enzyme supplementation the number of pathogenic fungi identified were still four species same as those fed the control diet without enzyme supplementation but the number of pathogenic fungi identified in the gut of birds fed diet with $10 \% \mathrm{RH}$ with enzyme supplementation had reduced to two species; (Fusarium solani and Rhizopus stolonifer) while Rhizopus stolonifer was the only opportunuistic/pathogenic fungus identified in the gut of those birds fed diets with 20 or $30 \%$ RH. 


\section{Microbial modulating effect of xylanase enzyme}

Table 7: Identified microbes (fungi and bacteria) in the gastrointestinal tract of broiler chicken with or without enzyme supplemented rice husk

\begin{tabular}{|c|c|c|c|c|}
\hline Without Enzyme & Beneficial Fungi & $\begin{array}{l}\text { Opportunistic/pathogenic } \\
\text { Fungi }\end{array}$ & Beneficial Bacteria & $\begin{array}{l}\text { Pathogenic } \\
\text { Bacteria }\end{array}$ \\
\hline Control & $\begin{array}{l}\text { Saccharomyces } \\
\text { cerevisiae }\end{array}$ & $\begin{array}{l}\text { Fusarium solani, Rhizopus } \\
\text { stolonifer, Aspergillus niger, } \\
\text { Aspergillus flavus }\end{array}$ & Bacillus subtilis & $\begin{array}{l}\text { E. coli, } \\
\text { Streptococcus sp, } \\
\text { Staphylococcus } s p \text {. }\end{array}$ \\
\hline $10 \%$ & $\begin{array}{l}\text { Saccharomyces } \\
\text { cerevisiae }\end{array}$ & $\begin{array}{l}\text { Fusarium solani, Rhizopus } \\
\text { stolonifer, Aspergillus niger, } \\
\text { Aspergillus flavus }\end{array}$ & Bacillus subtilis & $\begin{array}{l}\text { E. coli, } \\
\text { Streptococcus sp, } \\
\text { Staphylococcus } \\
\text { sp, Clostridium sp. }\end{array}$ \\
\hline $20 \%$ & $\begin{array}{l}\text { Saccharomyces } \\
\text { cerevisiae }\end{array}$ & $\begin{array}{l}\text { Fusarium solani, Rhizopus } \\
\text { stolonifer, Aspergillus niger, } \\
\text { Aspergillus flavus }\end{array}$ & Bacillus subtilis & $\begin{array}{l}\text { E. coli, } \\
\text { Streptococcus sp, } \\
\text { Staphylococcus } \\
\text { sp, Clostridium spp, } \\
\text { Campylobacter, } \\
\text { Salmonella sp. }\end{array}$ \\
\hline $30 \%$ & $\begin{array}{l}\text { Saccharomyces } \\
\text { cerevisiae }\end{array}$ & $\begin{array}{l}\text { Fusarium solani, Rhizopus } \\
\text { stolonifer, Aspergillus niger, } \\
\text { Aspergillus flavus }\end{array}$ & Bacillus subtilis & $\begin{array}{l}\text { E. coli, } \\
\text { Streptococcus sp, } \\
\text { Staphylococcus } \\
\text { sp, Clostridium spp, } \\
\text { Campylobacter, } \\
\text { Salmonella spp. }\end{array}$ \\
\hline \multicolumn{5}{|l|}{ With Enzyme } \\
\hline Control & $\begin{array}{l}\text { Saccharomyces } \\
\text { cerevisiae }\end{array}$ & $\begin{array}{l}\text { Fusarium solani, Rhizopus } \\
\text { stolonifer, Aspergillus niger, } \\
\text { Aspergillus flavus }\end{array}$ & $\begin{array}{l}\text { Bacillus subtilis and } \\
\text { Lactobacillus sp }\end{array}$ & $\begin{array}{l}\text { E. coli and } \\
\text { Streptococcus sp. }\end{array}$ \\
\hline $10 \%$ & $\begin{array}{l}\text { Penicilium } \\
\text { chrysogenum, } \\
\text { Saccharomyces } \\
\text { cerevisiae }\end{array}$ & $\begin{array}{l}\text { Fusarium solani, Rhizopus } \\
\text { stolonifer }\end{array}$ & $\begin{array}{l}\text { Bacillus subtilis, } \\
\text { Lactobacillus sp and } \\
\text { Bifidobacterium }\end{array}$ & Streptococcus sp. \\
\hline $20 \%$ & $\begin{array}{l}\text { Penicilium } \\
\text { chrysogenum, } \\
\text { Saccharomyces } \\
\text { cerevisiae }\end{array}$ & Rhizopus stolonifer & $\begin{array}{l}\text { Bacillus subtilis, } \\
\text { Lactobacillus sp and } \\
\text { Bifidobacterium }\end{array}$ & $\begin{array}{l}\text { E. coli and } \\
\text { Streptococcus sp. }\end{array}$ \\
\hline $30 \%$ & $\begin{array}{l}\text { Penicilium } \\
\text { chrysogenum, } \\
\text { Saccharomyces } \\
\text { cerevisiae }\end{array}$ & Rhizopus stolonifer & $\begin{array}{l}\text { Bacillus subtilis, } \\
\text { Lactobacillus sp and } \\
\text { Bifidobacterium }\end{array}$ & Streptococcus sp. \\
\hline
\end{tabular}

Table 7 shows the effects of dietary levels of RH with or without enzyme supplementation on the summary of the identified bacteria in the crop, ileum and caecum pooled together. Increase in dietary levels of RH from 0 to $30 \%$ had no effect on the number of beneficial bacteria identified (Bacillus subtilis; was the only one found) while the pathogenic bacteria identified were increasing in number as dietary level of RH was also increasing. Three genera of pathogenic bacteria were identified in the gut of birds fed the control diet namely; $E$. coli, Streptococcus sp and Staphylococcus $s p$. In the gut of birds fed diet with $10 \% \mathrm{RH}$, four genera of pathogenic bacteria were identified (E. coli, Streptococcus, Staphylococcus and Clostridium species). In the gut of those birds fed diets with 20 or $30 \%$ RH six genera of pathogenic bacteria were identified namely; E. coli, Streptococcus, Staphylococcus, Clostridium, Campylobacter and Salmonella species. Enzyme supplementation of the dietary levels of RH had increase effect on the number of beneficial bacterial identified and a reduced effect on the number of the pathogenic bacteria identified. Two beneficial bacteria genera were identified in the gut of bird fed the enzyme supplemented control diet namely; Bacillus sp. and Lactobacillus sp. 


\section{Aderibigbe, Atteh and Okukpe}

Those birds fed enzyme supplemented dietary levels of RH had three (3) beneficial bacteria (Lactobacillus sp, Bacillus subtilis and Bifidobacterium) identified in their gut respectively. For birds fed the enzyme supplemented control diet the number of pathogenic bacteria had reduced to two (2) (E. coli and Streptococcus sp) compared to the control diet without enzyme supplementation. The number of pathogenic bacteria identified in the gut of birds fed diet with $20 \% \mathrm{RH}$ with enzyme supplementation were two (2); (E. coli and Streptococcus sp.) while those of birds fed diets with 10 or $30 \% \mathrm{RH}$ with enzyme supplementation was one (1); (Streptococcus sp.) respectively.

\section{Discussion}

The significant improvements observed in the group fed enzyme supplemented diets may be due to the ability of the birds to utilize the dietary fibre and other nutrients in the feed due to the activities of the enzyme. This made it possible for birds fed enzyme supplemented diets to consume less feed, yet their energy requirement was met, converted feed efficiently and had a better feed conversion ratio. This result is in agreement with the findings of Nadeem et al. (2005) who reported that reduction of feed intake was due to enhancement of feed, digestibility and nutrient availability. Birds are able to meet their energy requirement faster than when diets are not supplemented with enzymes (Lee et al., 2010). Marquardt et al. (1994) also reported that the ability of the birds to facilitate access of enzymes to intracellular starch granules, proteins and other nutrients by breaking down otherwise intact bonds between non-starch polysaccharides was the reason for better performance in birds fed enzyme supplemented diets. Bedford (2000) reported that high digesta viscosity causes reduced feed digestion and slows the rate of nutrient absorption and Lee et al. (2010) reported that enzymes reduce digesta viscosity induced by the presence of high molecular weight non-starch polysaccharides.

The significant decline in performance as the dietary level of RH increased can be attributed to decreased metabolizable energy and increased dietary fibre in the diets as the inclusion level of RH increased. Wu et al. (2004) reported that the chicken is known to be especially sensitive to dietary energy concentration and Yunusa et al. (2014) report sensitivity of chicken to dietary fibre in feed. Also, the digesta viscosity is known to increase with increase in fibre level and Montagne et al. (2003) reported that high digesta viscosity caused feed digestion to reduce which subsequently slow down the rate of nutrient absorption.

This reduction in percentage cost of raising $1 \mathrm{Kg}$ of broilers at $0 \% \mathrm{RH}$ inclusion level with enzyme supplementation was due to faster growth rate of broilers by enzyme supplementation at this inclusion level. The percentage increase in cost of producing $1 \mathrm{Kg}$ broiler in enzyme supplemented diets can be attributed to the extra cost of feed enzyme incurred. While others without enzyme supplementation was due to poor feed conversion ratio of the birds which may be as a result of poor nutrient retention. This partially supports one of the reasons given by Hosamani et al. (2001) which was that profit increased due to faster growth rate of broilers by enzyme supplementation but was not in accordance with low feed cost as the feed might not be readily digestible by the birds thereby leading to consumption of more quantity of feed leading to higher cost of production.

The significant reduction with increased dietary $\mathrm{RH}$ in protein retention in the interaction with enzyme and treatment 


\section{Microbial modulating effect of xylanase enzyme}

across all treatments could have been caused by increased dietary fibre level which hindered the digestion and utilization of crude protein in the diets. Oladunjoye and Ojebiyi (2010) reported a similar effect when RH was fed with or without enzyme to broiler chickens. The cause was attributed to high fibre in the diets. Bezkorovainy (2001) also reported that high fibre diets reduced digestibility of the diets stating that birds are sensitive to fibre content of the feed.

Effect of enzyme action which might have acted on the fibre content of the feed to improve the nutritional value might be the reason for groups fed enzyme supplemented diets having a better nutrient retention than groups without enzyme supplementation. Angelovicova et al. (2005), Khan et al. (2006) and Oladunjoye and Ojebiyi (2010) reported that the use of exogenous microbial enzymes improved the nutritional value of high fiber diets. Reid and Robert (2002) stated that the use of exogenous microbial enzymes improved nutrient digestibility, destroy antinutritional factors and manipulate gut flora population as well as supplementing endogenous enzymes.

Significant reduction in the crude protein retention associated with increased rice husk inclusion was caused by increased dietary fibre which reduced the utilization of the dietary protein as the level of rice husk increased. This agrees with the work of Koong et al. (1985) and HosseiniVashan et al. (2010) who reported that high dietary fibre (feed diluents) decrease nutrient utilization in monogastric.

The significantly higher percentage weight of spleen in diets without enzyme supplementation could be as a result of higher haemoglobin level which indicated production of higher red blood cell in diets without enzyme supplementation as the spleen is known to involve in the production and removal of blood cells (Okukpe et al., 2016). The higher percentage weight of spleen in group fed $0 \%$ rice husk diets could be as a result of relatively higher haemoglobin level and significantly higher white blood cells as compared to other diets as spleen is known to be involved in the production and removal of blood cells. The significantly lower percentage weight of abdominal fat in RH based diets as compared to diet with $0 \%$ $\mathrm{RH}$ inclusion level might be as a result of high level of fibre which acts as diluent thereby preventing excess fat deposition in the body of the animals. This is in agreement with Duke (1986) and Oyawoye and Nelson (1999) who reported that fibrous feeds, because of their lower content and availability of energy tend to promote better carcasses with higher lean meat and lower fat contents.

Enzyme inclusion at 0\% RH inclusion level resulted in a significantly $(\mathrm{P}<0.05)$ lower $\mathrm{pH}$ value. Acidic condition has been reported by Hertland et al. (2005) to aid digestion. This may be the reason why birds fed enzyme supplemented $0 \% \mathrm{RH}$ diet had a better performance than other diets. Enzyme supplementation resulted to a significant lower faecal coliform count and a numerical higher Lactobacillus population (Jorgensen et al., 1996; Montagne et al., 2003). This could be a pointer to the prebiotic property of $\mathrm{RH}$ as Lactobacillus population increased to significantly reduce the faecal coliform count.

The significant effect of dietary inclusion of rice husk on TCC and LBC can be attributed to the prebiotic properties of $\mathrm{RH}$ as those with RH had a similar TCC and LBC value which was significantly higher than the control diet. Although $\mathrm{RH}$ inclusion resulted to a higher TCC, there was a numerical decrease in the FCC and a significant increase in the LBC of groups 


\section{Aderibigbe, Atteh and Okukpe}

fed rice husk based diets as compared to the control diet (without rice husk inclusion). The similar $\mathrm{pH}$ in groups fed rice husk which was higher than that of $0 \%$ rice husk diet might be the reason for better nutrient utilization in the $0 \%$ rice husk diet as acidic condition has been reported to aid digestion (Yadi and Yana, 2011; Ohimain and Ofongo, 2013). Bach (1997) corroborated by Hertland et al. (2005) reported that coarse feed particles, such as those provided by the fibrous feeds; remain longer in the upper part of the GIT and as such, birds with lower $\mathrm{pH}$ (more acidic) in the upper part of the GIT will be able to digest and utilize fibre more than those with higher pH. Mabelebele et al., (2014) reported that lower $\mathrm{pH}$ value of crop and gizzard in Venda chickens as compared to broilers may be the reason why indigenous chickens tend to digest fibre better than broiler chickens. The significantly higher value for fungi count in the groups fed $20 \%$ rice husk inclusion may be as a result of adequate quantity of carbohydrate fibre called oligosaccharides present in the rice husk. Fungi grow and develop in the presence of starch; the development of a good mold fungus produces the enzyme cellulase spurred in large quantities that can be used to remodel and lower crude fiber (Adams, 1993). Thrope and Beal (2001), supported by Li et al. (2008) reported that cellulase is an enzyme that can decide $\beta$ glycosides bond (1.4) on cellulose and Binns (2013) concluded that high population of fungus can increase the crude protein content of the substrate as the mold is a source of single cell protein. This may be the reason behind $20 \%$ rice husk inclusion having similar protein retention as $10 \%$ rice husk inclusion level.

\section{Conclusion}

The study showed that replacement of maize with Rice Husk irrespective of levels supplemented with $100 \mathrm{ppm}$ xylanase enzyme caused a reduction in feed intake and an increase in weight gain and better FCR. In all these parameters, it is observed that birds fed diet with $10 \% \mathrm{RH}$ supplemented with xylanase enzyme outperformed birds fed diets with 20 or $30 \%$ RH supplemented with xylanase enzyme and closer to the birds fed the control diet which was with better FCR. It can be deduced that enzyme supplementation of $\mathrm{RH}$ helped in increasing and improving protein, ether extract and fibre digestibilities. The result obtained for the weights of vital organs in this trial showed that the birds were in good health conditions during the trial period. The result of identification of microbes (Fungi and Bacteria) in this study showed that dietary levels of RH (10, 20 or 30\% inclusion) with supplementation of enzyme xylanase enhanced the growth of beneficial microbes which resulted in inhibition or elimination of the opportunistic/pathogenic microbes. The result of the cost benefit analysis also showed that $10 \%$ inclusion level of Rice Husk supplemented with xylanase enzyme gave the best result of a beneficiary reduction in the cost of production with the best improved broiler performance.

\section{References}

A. O. A. C. 2008. Official Methods of Analysis: Association of Analytical and Applied Chemists (18th edition) Washington D.C. USA.

Adams, E. A. 1993. Non-starch polysaccharides and their digestion in poultry. Feed compounder 13: 19 -21 .

Angelovicova, M., Jan, M., Marek, A. and Miroslava, K. 2005. Effect of enzyme addition to wheat based diets in broiler. Trakya University J. Sci., 6(1): 29-33.

Bach Knudsen, K. E. 1997. Carbohydrate 


\section{Microbial modulating effect of xylanase enzyme}

and lignin contents of plant materials used in animal feeding. Anim. Feed Sci. Technol. 67: 319 338.

Baurhoo, B., Philip, L. and Ruiz-Feria, C. A. 2007. Effects of purified $1 \mathrm{ig} n$ i $\mathrm{n}$ a $\mathrm{d}$ a $\mathrm{n} \mathrm{n}$ a $n$ oligosaccharides on intestinal integrity and microbial population in the ceca and litter of broiler chickens. Poult. Sci. 86, 1070 1078.

Bedford, M.R. 2000. Exogenous enzymes in monogastric nutrition - their current value and future benefits. Anim. Feed Sci. Techn. 86: 1-1.

Bengmark, S. 2001. Pre-, pro- and symbiotics. Current Opinion in Clinical Nutrition and Metabolic Care 4:571-579.

Bezkorovainy, A. 2001. Probiotics: Determinants of survival and growth in the gut. Am. J. Clin. Nutr., 73(suppl.): 399S-405S.

Binns, N. 2013. Probiotics, Prebiotics and the Gut Microbiota. ILSI Europe Concise Monograph Series. Pp 1-40.

Bruggencate, S. J. M. T., BoveeOudenhoven, I. M. J., LettinkWissink, M. L. G., Katan, M. B. and Van Der Meer, R. 2008. "prebiotic oligosaccharides and the enterohepatic circulation of bile salt in rats. Am. J. Physiol-Gastr. L. 294: 540-547.

Chio, K. H., Namkung, H. and Paik, I. K. 1994. Effects of dietary fructolligosaccharides on the suppression of intestinal colonization of Salmonella typhimurium in broiler chickens. Korean J. Anim. Sci., 36: 271-284.

Duke, G. E. 1986. Alimentary Canal: Anatomy, Regulation of Feeding and Motility. In: Avian Physiology,
Sturkie, P.D. (Ed.). Springer

Verlag, New York, pp: 269-288.

Gallinger, C. I., Suárez, D. M. and Irazusta, A. 2004. Effects of rice bran inclusion on performance and bone mineralization in broiler chicks. Journal of Applied Poultry Research 13:183-190.

Hertland, H., Svihus, B. and Choct, M. 2005. Role of insoluble fiber on gizzard activity in layers. J. Applied Poul. Res. 14: 38-46.

Hosamani, S. V., Shivakumar, M. C., Ku l k k a r n i, V. S. a nd Harapanahailli, M. D. 2001. Effect of supplementing dietary enzymes on the performance of broilers. Karnataka Journal of Agricultural sciences 14:10461048

Hosseini-Vashan, S. J., Golian, A., Motaghinia, Gh., Namvari, M. and Hamedi, M. 2010 . Comparison of Growth Performance and Carcass Characteristics of Broiler Chickens Fed Diets with Various Energy and Constant Energy to Protein Ratio. Journal of Animal and Veterinary Advances 9(20): 2565-2570

Jorgensen, H. Z., XinQuan, K. E., Krudse, B. O. and Zhao, X. Q. 1996. The influence of dietary fibre source and level on development of the gastrointestinal tract digestibility and energy metabolism in broiler chickens. $B r$. J. Nutr. 75:379-395.

Kalantar, M., Khajali, F., Yaghobfar, A., Pourreza, J. and Akbari, M.R. 2014. Broiler Chicken Growth Performance, Ileal Microbial Population and Serum Enzyme Activity Affected By Dietary Source of Non-Starch 
P o l y s a c h a rides a s Supplemented With or Without Enzymes. Global Journal of Animal Scientific Research. 2: 3.

Khan S.H., Sardar R. and Siddique B. 2006. Influence of enzymes on performance of broilers fed sunflower corn based diets. Pakistan Vet.J. 26 (3): 109-114.

Koong, L.J., Ferrell, C.L. and Nienaber, J.A. 1985. Assessment of interrelationships among levels of intake and production, organ size and fasting heat production in growing animals. J. Nutr. 115: 1383-1390.

Lee S.Y., Kim J.S., Kim J.M., Ki An B. and Kang C.W. 2010. Effects of multiple enzyme (Rovabio ${ }^{\circledR}$ Max) containing carbohydrolases and phytase on growth performance and intestinal viscosity in broiler chicks fed corn-wheat-soybean meal based diets. Asian-australs J. Anim. Sci.23: 1198 - 1204.

Li, X., Liu, L.Q. and Xu, C.L. 2008. Effects of supplementation of fructo-oligosaccharide and/or Bacillus Subtilis to diets on performance and intestinal microflora in broilers. Archiv für Tierzucht 51: 64-70.

Mabelebele, M. Alabi, O.J. Ng ambi, J.W. Norris, D. and Ginindza, M.M. 2014. Comparison of Gastrointestinal Tracts and $\mathrm{pH}$ Values of Digestive Organs of Ross 308 Broiler and Indigenous Venda Chickens Fed the Same Diet. Asian Journal of Animal and Veterinary Advances 9: 71-76.

Marquardt R. R., Boros D. D., Guenter W and Crow G. 1994. The nutritive value of barley, rye, wheat and corn for young chicks as affected by the use of Trichoderma reesei enzyme preparation. Anim. Feed Sci. Tech. 45:363-378.

Montagne, L., Pluske, J.R. and Hampson, D.J. 2003. A review of interactions between fibre and the intestinal mucosa and their consequences on digestive health in young non-ruminant animals. Feed Sci. Tech. 108: 95- 117.

Nadeem, M. A., Anjum, M. I., Khan, A. G. and Azim, A. 2005. Effect of dietary supplementation of nonstarch polysaccharide degrading enzymes on growth performance of broiler chicks. Pakistan Vet. J. 25(4): 1

National Research Council 1994. Nutrient requirements of Poultry, $9^{\text {th }}$ Rev. Ed. National Academy Press, Washington, DC.

Ohimain, E. I. and Ofongo, R. T. S. 2013. Effect of enzyme supplemented diet on gut microflora, digesta ph and performance of Broiler chickens. Journal of Microbiology, Biotechnology and Food Sciences. 3(2): 127-131.

Okukpe, K. M., Adeyemo, A. D., Adua, M., Omotayo, O. O., Yusuf, O. A., Aderibigbe, T. A., Opowoye, I. O., Ogunsola, F. O. and Osho, B. 2016. Stress modulating effect of crude leaf extract of Vernonia amygdalina in captive grasscutter (Thryonomys swinderianus). Wayamba Journal of Animal Science 2012-578X: P1445-P1459.

Oladunjoye, I. O. and Ojebiyi, O. O. 2010 . P e r f o r m a c e Characteristics of Broiler Chicken (Gallus gallus) Fed Rice (Oriza sativa) Bran with or Without Roxazyme G2G. International Journal of Animal and Veterinary Advances 2(4): 135 140. 
Oyawoye, E. O. and Nelson, F. S. 1999. Optimum level of inclusion of rice offal in the diet of young cockerels. Proc. Of the $26^{\text {th }}$ Annual Conference of Nigerian Society of Animal Production, $21-25^{\text {th }}$ March, Ilorin, pp. $263-266$.

Reid, G. and Robert, F. 2002. Alternatives to antibiotic use: Probiotics for the gut. Anim. Biotechnol. 13: 97 - 112. http://dx.doi.org/10.1081/ABIO $\underline{-120005773}$

Roberfroid, M. 2007. Prebiotics: the concept revisited. J. Nutr. 137(3 Suppl. 2): 830S-837S. PMID: 17311983.

SAS 2008. SAS Institute Inc. 2008. ASA/STAT Users Guide version 9.2 for windows. Carry, North Carolina, USA. SAS Institute Inc.

Selle, P. H. and Ravindran, V. R. 2007. Microbial phytase enzyme in poultry nutrition. A Review, Animal Feed Science Technology 35: 1 41.

Thrope, J. and Beal, J. D. 2001. Vegetable proteins meals and the effects of enzymes. Pp: 125 - 143 in Enzymes in Farm Animal Nutrition. M.R. Bedford and G.G. Partridge, Eds. CABI Publishing Series.

Wang, Z. R., Qiao, S. Y., Lu, W. Q. and Li, D. F. 2005. Effects of enzyme supplementation on performance, nutrient digestibility, gastrointestinal morphology and volatile fatty acid profiles in the hindgut of broilers fed wheat-based diets. Poult. Sci. 84: 875-881.
Wu, Y. B., Ravidran, V., Thomas, D. G., Birtles, M. J. and Hendriks, W. H. 2004. Influence of phytase and xylanase, individually or in combination, on performance, apparent metabolisable energy, digestive tract measurements and gut morphology in broiler fed wheat-based diets containing adequate level of phosphorus. $B r$. Poult. Sci. 45: 76-84.

Yadi, P. and Yana, S. 2011. The influence of Palm Kernel Cake and Rice Bran Fermentation Product Mixture to the Broiler Carcass Quality. Internat. J. of Waste Resources 1(2): 15-17.

Yunusa, Y., Doma, U. D., Zahraddeen, D., Umar, A. and Abubakar, S. B. 2014. Carcass and Gut Characteristics of Broiler Chicken Fed Different Energy Source. International Journal of Poultry Science 13 (9): 525-529.

Received: $20^{\text {th }}$ September, 2018 Accepted: $21^{\text {st }}$ December, 2018 